УДК 678.744.342:547.9

\title{
СИНТЕЗ НОВЫХ БИОЛОГИЧЕСКИ АКТИВНЫХ ПОЛИМЕРНЫХ БИОКОНЪЮГАТОВ НА ОСНОВЕ ЛУПАНОВЫХ АЛЛИЛАМИДОВ
}

\author{
() М.Н. Горбунова", Г.Ф. Крайнова, И.А. Толмачева, В.В. Гриико \\ Институт технической химии Уральского отделения РАН, ул. Академика \\ Королева 3, Пермь, 614013 (Россия), e-mail: mngorb@newmail.ru
}

\begin{abstract}
На основе легко выделяемого из коры березы (Bétula) тритерпеноида бетулина синтезированы бетулоновая и 2-гидроксимино-бетулоновая кислоты, взаимодействием которых с аллиламином в присутствии оксалил хлорида и триэтиламина получены соответствующие аллиламиды. Установлено, что полученные аллиламиды с низкими скоростями сополимеризуются с акрилонитрилом и N-винилпирролидоном в присутствии радикальных инициаторов с образованием статистических сополимеров. Полученные сополимеры обладают цитотоксической активностью в отношении культуры MS и являются перспективными для разработки новых биологически активных полимерных биоконъюгатов.
\end{abstract}

Ключевые слова: лупановые аллиламиды, радикальная сополимеризация, цитотоксическая активность.

Работа выполнена при финансовой поддержке РФФИ (грант № 15-03-01701-а) и программы Президиума РАН Фундаментальные науки - медицине».

\section{Введение}

В последнее время актуальна разработка методов синтеза полимерных терпенсодержащих нанобиоконъюгатов путем модификации солюбилизирующих полимерных матриц биологически активными тритерпеноидами. Среди терпеноидов растительного происхождения цитотоксическую активность в отношении раковых клеток показала бетулоновая кислота [1], выдающийся фармакологический потенциал которой раскрывается по мере расширения исследования ее производных [2]. Основными недостатками известных тритерпеноидов являются, во-первых, необходимость создания в организме большой концентрации дорогостоящего препарата, поскольку низкомолекулярные вещества быстро выводятся из организма, во-вторых, природные тритерпеноиды практически нерастворимы в воде, поэтому возникают сложности при их введении. Синтез полимерных производных низкомолекулярных биологически активных веществ дает возможность создавать более совершенные лекарственные формы, в которых снижается токсичность, повышается эффективность, достигается пролонгация действия препаратов. Применение полимерных матриц способствует повышению водорастворимости тритерпеноидов и, таким образом, упрощает способ введения лекарств. Кроме того, получение полимерных конструкций позволяет в большинстве случаев создавать новые лекарственные

Горбунова Марина Николаевна - старший научный сотрудник лаборатории природных и биологически активных соединений, кандидат химических наук, e-mail: mngorb@newmail.ru

Крайнова Гульназ Фаизовна - научный сотрудник лаборатории природных и биологически активных соединений, кандидат химических наук

Толмачева Ирина Анатольевна - старший научный сотрудник лаборатории природных и биологически активных соединений, кандидат химических наук Грижко Виктория Викторовна - заведующая лабораторией природных и биологически активных соединений, кандидат химических наук формы из тритерпеноидов, приготовить которые не представляется возможным вследствие плохой растворимости последних в воде. В этом случае удается реализовать в полной мере биологическую активность низкомолекулярного лекарственного вещества.

Методом радикальной полимеризации получены полиуретаны на основе бетулина и изоцианата [3], полиакрилаты на основе бетулина и 2,3-эпоксипропилакрилата [4], эпоксиполимеры на основе диглицидилового эфира бетулина [5].

\footnotetext{
* Автор, с которым следует вести переписку.
} 
Высокая биологическая активность производных бетулина - бетулоновой [6] и 2-гидроксиминобетулоновой кислот [7] обусловливает перспективность использования их аллиламидных производных в получении новых (со)полимеров. Надо отметить, что в литературе отсутствуют данные о возможности вовлечения данных тритерпеноидов в реакции радикальной полимеризации.

Работа посвящена синтезу новых сополимеров на основе аллиламидов бетулоновой и 2-гидроксиминобетулоновой кислот и исследованию их цитотоксической активности.

\section{Экспериментальная часть}

Бетулин получали экстракцией бересты березы (Bétula) по методике [8].

Бетулоновую кислоту получали по известной методике [6] из бетулина, 2-гидроксиминобетулоновую кислоту получали из бетулоновой кислоты по методике [9].

Аллиламиды бетулоновой и 2-гидроксиминобетулоновой кислот получали по методике [10].

Акрилонитрил (АН) фирмы Alfa Aesar очищали перегонкой, использовали фракцию с $\mathrm{T}_{\text {кип. }} 78{ }^{\circ} \mathrm{C}$, $n_{\mathrm{D}}^{20}=1,3910$.

$N$-Винилпирролидон (ВП) фирмы Lancaster сушили над КОН и перегоняли в вакууме, использовали фракцию с $\mathrm{T}_{\text {кип }}=65^{\circ} \mathrm{C} / 1,5$ мм рт.ст., $n_{\mathrm{D}}^{20}=1,5117$.

Инициатор - динитрил азобисизомасляной кислоты (ДАК) и растворители, используемые в работе, после очистки общепринятыми методами по своим характеристикам соответствовали литературным данным.

Сополимеризацию аллиламидов проводили в ампулах в атмосфере аргона при температуре $70-90{ }^{\circ} \mathrm{C}$ в массе и в растворах метанола и хлороформа в присутствии ДАК. Растворители были выбраны с учетом растворимости исходных аллиламидов. По окончании реакции полученные сополимеры осаждали в ТГФ. Очистку сополимеров проводили трехкратным переосаждением из метанола в ТГФ. Очищенные сополимеры сушили в вакууме до постоянной массы при $50{ }^{\circ} \mathrm{C}$. Состав сополимеров рассчитывали по результатам элементного анализа.

Эффективные константы сополимеризации $r_{1}$ и $r_{2}$ рассчитывали методами Файнемана - Росса [11] и Келена - Тюдеша [12].

Спектры ЯМР ${ }^{1} \mathrm{H}$ регистрировали на спектрометре Varian Mercury с рабочей частотой 300 МГц. В качестве растворителя использовали $\mathrm{CDCl}_{3}$, внутренний стандарт - гексаметилдисилоксан.

Культуры клеток человека A549 (карцинома легкого), RD (рабдомиосаркома) и MS (меланома) выращивались в среде DMEM (для A549 и RD) и RPMI 1640 (для MS) с добавлением 10\% эмбриональной телячьей сыворотки, $2 \mathrm{MM} \mathrm{L-глутамина} \mathrm{и} 1 \%$ гентамицина в качестве антибиотика при $37^{\circ} \mathrm{C}$ и $5 \% \mathrm{CO}_{2}$ во влажной атмосфере.

Цитотоксическую активность сополимеров исследовали в отношении клеточной линии MS, полученной из НИИ экспериментальной диагностики и терапии опухолей Российского онкологического научного центра им. Н.Н. Блохина РАМН (г. Москва). Клетки рассевали в 96-луночные микропланшеты и культивировали в питательной среде DMEM с добавлением $10 \%$ эмбриональной сыворотки теленка и $0,3 \%$ глютамина при $37{ }^{\circ} \mathrm{C}$ в атмосфере $5 \% \mathrm{CO}_{2}$ в $\mathrm{CO}_{2}$-инкубаторе Isotemp Barnstead (США). Через 24 ч в лунки планшета вносили испытуемые соединения в концентрации 100 мкМ раствора в ДМСО с последующим серийным разведением до 1,56 мкМ. Выживаемость клеток оценивали через 72 ч инкубации клеток с исследуемыми соединениями с помощью МТT-теста [13] на спектрофотометре FLUOstar OPTIMA BMG Labtech GMBH (Германия).

\section{Обсуждение результатов}

Тритерпеноиды повсеместно распространены в природном мире, в наземной и морской фаунах насчитывается более 4000 соединений, отличающихся структурным разнообразием и широким спектром биологической активности. Одним из богатейших и уникальных по составу сырьевых источников является береста березы, активное исследование экстрактивных веществ которой начато в XX в. [14-22]. Бетулин, на долю которого приходится основная часть экстрактивных веществ бересты, является одним из наиболее известных природных соединений. Бетулин впервые выделен из бересты и описан еще в 1788 г. Его содержание в бересте березы достигает $35 \%$ вес. [22]. 
Взаимодействием хлорангидридов бетулоновой и 2-гидроксиминобетулоновой кислоты с аллиламином в присутствии триэтиламина при температуре $30{ }^{\circ} \mathrm{C}$ были получены аллиламиды бетулоновой (ААБ) и 2-гидроксиминобетулоновой (ААГБ) кислот (рис. 1). Наличие амидной группы подтверждено данными ИК и ЯМР ${ }^{1} \mathrm{H}$ спектроскопии.

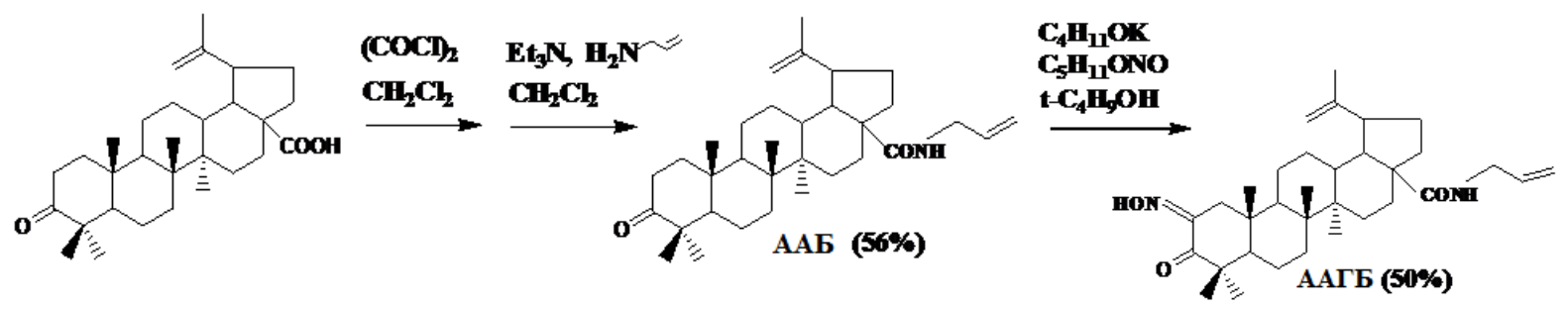

Рис. 1. Синтез аллиламидов бетулоновой (ААБ) и 2-гидроксиминобетулоновой (ААГБ) кислот

Известно, что в отличие от мономеров винилового ряда, обычно легко полимеризующихся под действием радикальных инициаторов до высокомолекулярных продуктов, моноаллиловые мономеры общей формулы $\mathrm{CH}_{2}=\mathrm{CH}-\mathrm{CH}_{2}-\mathrm{X}$ полимеризуются по радикальному механизму с очень низкими скоростями и образуют олигомерные продукты $\left(\overline{P_{n}}=3 \div 30\right)[23,24]$. Столь резкие различия в поведении виниловых и аллиловых мономеров объясняются присутствием в молекулах последних $\mathrm{CH}_{2}$-групп в $\alpha$-положении к двойной связи. При атаке молекулы аллилового мономера активным радикалом наряду с присоединением по двойной связи с высокой вероятностью может произойти отрыв атома водорода от $\alpha-\mathrm{CH}_{2}$-группы. Это приводит к гибели исходного активного радикала и к образованию малоактивного аллильного радикала, стабилизированного внутренним сопряжением.

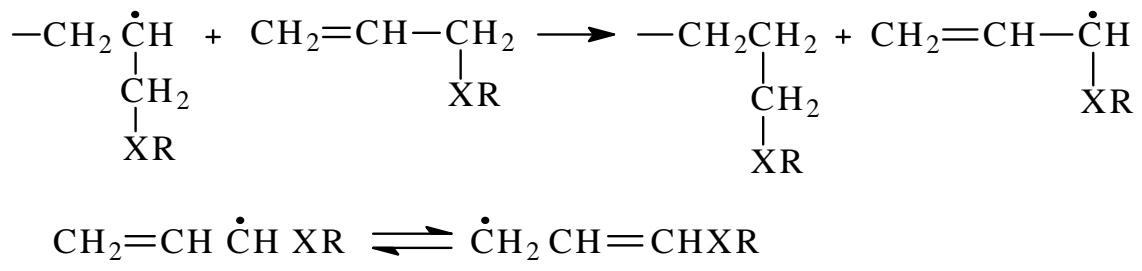

Хорошие результаты были получены в результате использования комплексообразователей: протонных и апротонных кислот, которые взаимодействуют с аллиловыми мономерами и промежуточными радикалами, изменяя вероятность продолжения цепи. Фундаментальные исследования в этом направлении выполнены В.А. Каргиным, В.А. Кабановым, В.П. Зубовым с сотр. [23, 25-32]. Установлено, что, используя комплексообразователи (протонные и апротонные кислоты), можно значительно увеличить вероятность продолжения цепи при полимеризации аллиловых мономеров. В частности, полимеризацией аллилового спирта в присутствии комплексообразователей $\left(\mathrm{CaCl}_{2}, \mathrm{ZnCl}_{2}\right)$ или неорганических кислот $\left(\mathrm{HCl}, \mathrm{H}_{3} \mathrm{PO}\right)_{4}$ получен полиаллиловый спирт с $\overline{\mathrm{P}}_{\mathrm{n}}=10^{3}$.

Еще одной возможностью эффективного вовлечения в полимеризацию аллиловых мономеров является их чередующаяся сополимеризация с мономерами-акцепторами. В этом случае определяющую роль играют донорно-акцепторные комплексы реагирующих частиц [33, 34].

Исследования показали, что аллиламин (ААМ) не гомополимеризуется и не сополимеризуется с ВП при вещественном инициировании [35]. Однако при использовании ААМ в протонированной форме (в виде аллиламмониевых солей) реакции сополимеризации протекают. Исследования сополимеризации гидрохлорида ААМ с ВП в различных средах (в воде, в вводно-этанольных, этанольных и метанольных растворах) показали, что сополимеризация протекает с достаточно высокой скоростью.

Анализ данных об относительных активностях аллиловых мономеров при сополимеризации с акрилонитрилом [36, 37] показывает, что в большинстве случаев константы сополимеризации аллиловых мономеров равны нулю либо существенно меньше констант, характерных для виниловых мономеров.

Таким образом, характер участия аллиловых мономеров в реакции сополимеризации определяется их малой активностью по сравнению с большинством виниловых мономеров. 
Проведенные нами исследования показали, что аллиламиды остаются инертными при гомополимеризации, но вступают в присутствии радикальных инициаторов в реакции сополимеризации с акрилонитрилом и N-винилпирролидоном с низкими скоростями.

Исследования радикальной сополимеризации ААБ и ААГБ с АН и ВП показали, что образующиеся сополимеры имеют статистическое распределение сомономерных звеньев в макромолекуле (рис. 2). Значения эффективных констант сополимеризации ААБ и ААГБ $\left(\mathrm{M}_{1}\right)$ с АН и ВП представлены в таблице 1 . Из представленных данных видно, что во всем исследуемом интервале концентраций полученные сополимеры обогащены звеньями винилового мономера.

При увеличении содержания аллиламидов в исходной мономерной смеси во всех сополимеризационных системах значения скорости сополимеризации значительно снижаются (рис. 3). Зависимости начальной скорости сополимеризации аллиламидов с АН и ВП $\left(\mathrm{M}_{2}\right)$ показывают, что скорость сополимеризации аллиламидов с АН выше, чем с ВП.

Температурную зависимость скорости реакции ААБ с ВП в растворе хлороформа исследовали в интервале температур 70-90 ㄷ. Значение эффективной энергии активации сополимеризации ААБ с ВП составляет $88,3 \pm 1,5$ кДж/моль.

С увеличением степени конверсии при полимеризации в массе в системах наблюдается «гельэффект». Это связано с возрастанием вязкости в отсутствие растворителя, в результате чего скорость эффективных соударений растущих макрорадикалов уменьшается и падает вероятность обрыва, что, в свою очередь, ведет к резкому возрастанию общей скорости реакции и возникновению «гель-эффекта». При сополимеризации в растворе «гель-эффект» отсутствует.

Методом ЯМР ${ }^{1} \mathrm{H}$ установлена структура полученных сополимеров (табл. 2). Полученные продукты представляют собой смесь сополимеров ААБ и ААГБ и их олигомеров. В спектрах продуктов реакции обнаружено также некоторое количество присоединений винилового мономера по двойной связи С-29.

\section{$\mathrm{m}_{2}$, мол.\%}

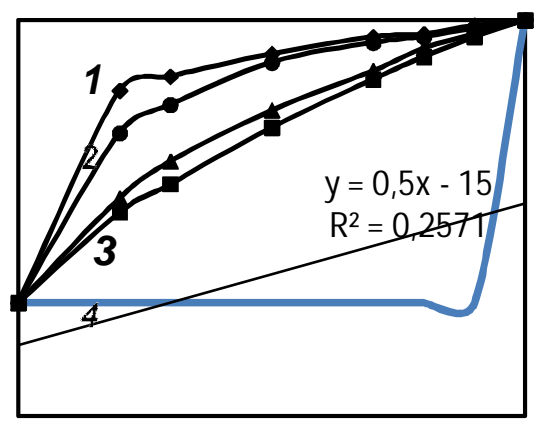

$\mathrm{M}_{2}$, мол. $\%$
$V \times 10^{4}$, mon/c

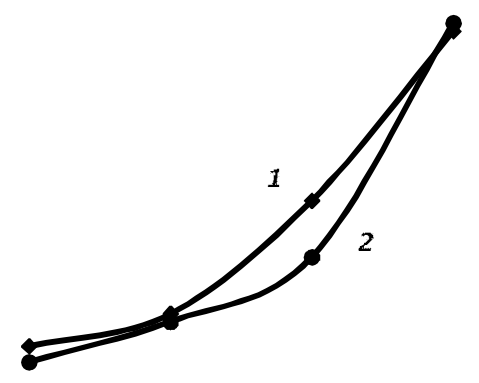

$\mathrm{M}_{2}$, моп. $\%$
Рис. 2. Зависимость состава сополимеров ААГБ (1, 3) и ААБ $(2,4)$ с АН $(1,2)$ и ВП $(3,4)$ от состава исходной смеси мономеров при полимеризации в хлороформе. $\mathrm{M}_{2}$ и $\mathrm{m}_{2}$ - мольные доли АН или ВП в исходной смеси и в сополимере соответственно. $\left[\mathrm{M}_{1}+\mathrm{M}_{2}\right]=5,7$ моль/л, [ДАК] = 0,13 моль/л, $\mathrm{T}=80{ }^{\circ} \mathrm{C}$
Рис. 3. Зависимость начальной скорости сополимеризации ААБ $\left(\mathrm{M}_{1}\right)$ с АН (1) и ВП (2) от состава исходной смеси мономеров. В массе [ДАК $]=3$ мас. $\%, \mathrm{~T}=80{ }^{\circ} \mathrm{C}$

Таблица 1. Значения эффективных констант сополимеризации ААБ и ААГБ с АН и ВП $\left(\mathrm{M}_{2}\right)$ при сополимеризации в массе (ДАК, $80{ }^{\circ} \mathrm{C}$ )

\begin{tabular}{c|c|c|c|c}
\hline Мономеры $\mathrm{M}_{1}$ & Мономеры $\mathrm{M}_{2}$ & $r_{1}$ & $r_{2}$ & $r_{I} r_{2}$ \\
\hline ААБ & \multirow{2}{*}{ АН } & $0,12 \pm 0,003$ & $4,65 \pm 0,20$ & 0,56 \\
ААГБ & & $0,02 \pm 0,001$ & $6,15 \pm 0,23$ & 0,12 \\
\hline ААБ & \multirow{2}{*}{ ВП } & $0,49 \pm 0,006$ & $1,48 \pm 0,11$ & 0,73 \\
ААГБ & & $0,35 \pm 0,050$ & $1,94 \pm 0,10$ & 0,68 \\
\hline
\end{tabular}


Таблица 2. Химические сдвиги ЯМР ${ }^{1} \mathrm{H}$ и ${ }^{13} \mathrm{C}$ новых аллиламидов и их сополимеров (DMSO)

\begin{tabular}{|c|c|c|}
\hline Структура & ИК-спектр & 'Н ЯМР-спектр \\
\hline ААБ-ВП & $\begin{array}{c}1644 \mathrm{~cm}^{-1}(\mathrm{CONH}) \\
1680 \mathrm{~cm}^{-1}, 1712 \mathrm{~cm}^{-1} \\
(\mathrm{C}=\mathrm{O}) \\
3361 \mathrm{~cm}^{-1}(\mathrm{NH})\end{array}$ & 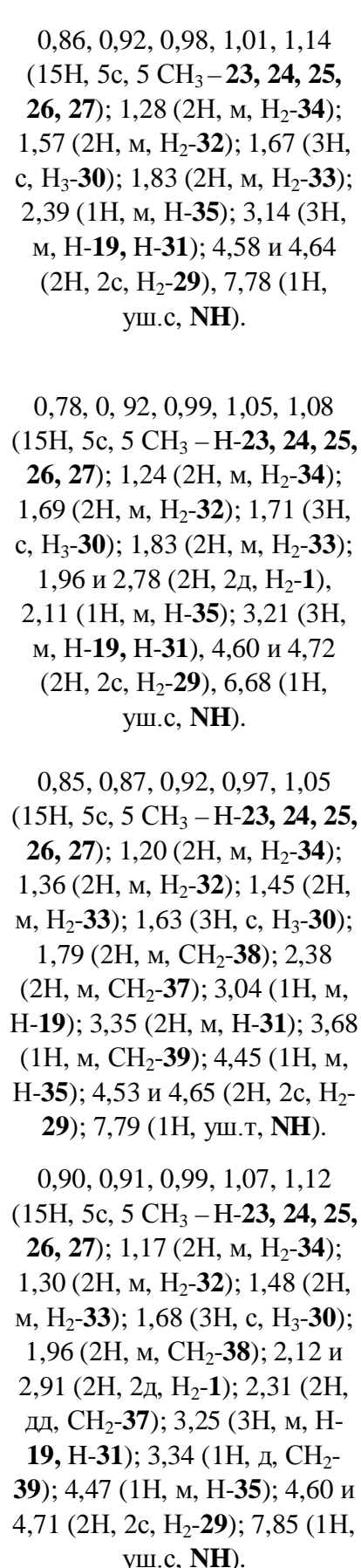 \\
\hline
\end{tabular}

Наиболее значимая область применения бетулинсодержащих субстанций - медицина. В обзорах [16, 17, 38-40] приведены данные об умеренной противоопухолевой, антибактериальной, фунгицидной и антивирусной активности бетулина. Таким образом, доступные природные пентациклические тритерпеноиды бетулин и бетулоновая кислота - являются перспективной базой для получения разнообразных тритерпеновых производных с высоким уровнем противоопухолевой и противовирусной активности.

Исследование цитотоксической активности новых сополимеров показало, что сополимер ААБ с ВП проявляет в 4 раза более высокую активность в отношении культуры MS по сравнении с исходным аллиламидом (табл. 3) и может быть использован в медицине и биотехнологии. 
Таблица 3. Цитотоксическая активность сополимеров ААБ (структуры представлены в табл. 2)

\begin{tabular}{|c|c|c|c|}
\hline & \multicolumn{3}{|c|}{ Концентрация соединения, которая вызывает гибель 50\% клеток $\left(\mathrm{IC}_{50}\right)$, мкM } \\
\hline & Меланома MS & Рабдомиосаркома RD & Карцинома легкого А549 \\
\hline ААБ & $187,84 \pm 7,32$ & $44,55 \pm 0,25$ & Нет эффекта \\
\hline сополимер ААБ-АН (2) & Нет эффекта & Нет эффекта & Нет эффекта \\
\hline сополимер ААБ-ВП (4) & $40,48 \pm 7,19$ & $171,90 \pm 1,11$ & Нет эффекта \\
\hline
\end{tabular}

\section{Выводы}

1. Установлено, что бетулоновая и 2-гидроксиминобетулоновая кислоты взаимодействуют с аллиламином с образованием соответствующих аллиламидов.

2. Полученные тритерпеновые аллиламиды сополимеризуются с акрилонитрилом и N-винилпирролидоном в присутствии радикальных инициаторов с образованием статистических сополимеров в линейной полимерной цепи.

3. Полученные новые полифункциональные сополимеры, потенциально обладающие комплексом ценных свойств (низкая токсичность, биологическая активность), могут найти применение в медицине и других областях.

\section{Список литературы}

1. Lee S.M., Min B.S., Lee C.G., Kim K.S., Kho Y.H. Cytotoxic triterpenoids from the fruits of Zizyphus jujuba // Planta Med. 2003. Vol. 69. N11. Pp. 1051-1054.

2. Tolstikova T.G., Sorokina I.V., Tolstikov G.A., Tolstikov A.G., Flekhter O.B. Biological activity and pharmacological prospects of lupane terpenoids: II. Semisynthetic lupane derivatives // Rus. J. Bioorg. Chem. 2006. Vol. 32 . N3. Pp. 291-307.

3. Era V., Jaaskelamen P., Ukkonen K. Fatty acid ersters from betulinol // J. Amer. Oil Chem. Soc. 1981. Vol. 58. N1. Pp. 20-23.

4. Era V., Mustonen T., Jaaskelainen P. Polyakrylates from betulinol // Mackromol. Chem. Rapid Commun. 1981. Vol. 2. Pp. 283-286.

5. А.с. № 1671666 (СССР). Диглицидиловый эфир на основе бетулина в качестве мономера для получения эпоксиполимеров с высокими диэлектрическими свойствами / М.С. Клебанов, В.А. Алдошин, И.П. Педько / 1991. C. 18.

6. Флехтер О.Б., Ашавина О.Ю., Бореко Е.И., Карачурина Л.Т., Павлова Н.И., Кабальнова Н.Н., Савинова О.В., Галин Ф.З., Николаева С.Н., Зарудий Ф.С., Балтина Л.А., Толстиков Г.А. Синтез 3-О-ацетилбетулинового и бетулонового альдегидов по Сверну и фармакологическая активность их оксимов // Химико-фармацевтический журнал. 2002. Т. 36. №6. С. 21-24.

7. Патент № 2477134 (РФ). Ингибитор репродукции ВИЧ-1 и вируса гриппа А / В.Ф. Еремин, Е.И. Бореко, И.А. Толмачева, В.В. Гришко /2013.

8. Флехтер О.Б., Нигматуллина Л.Р., Балтина Л.А., Карачурина Л.Т., Галин Ф.З., Зарудий Ф.С., Толстиков Г.А., Бореко Е.И., Павлова Н.И., Николаева С.Н., Савинова О.В. Получение бетулиновой кислоты из экстракта бетулина. Противовирусная и противоязвенная активность некоторых родственных терпеноидов // Химикофармацевтический журнал. 2002. Т. 36. №9. С. 26-28.

9. Толмачева И.А., Гришко В.В., Бореко Е.И., Савинова О.В., Павлова Н.И. Синтез и противовирусная активность 2,3-секопроизводных бетулоновой кислоты // Химия природных соединений. 2009. №5. С. 566-568.

10. Крайнова Г.Ф., Толмачева И.А., Горбунова М.Н., Гришко В.В. Синтез аллиламидов лупанового и А-секолупанового типа // Химия природных соединений. 2013. №2. С. 239-242.

11. Finemann M., Ross S.D. Linear method for determining monomer reactivity ratios in copolymerization // J. Polym. Sci. 1950. Vol. 5. Pp. 269-284.

12. Kelen T., Tüdős F. Analysis of the linear methods for determining copolymerization reactivity ratios. I. A new improved linear graphic method // J. Macromol. Sci., Chem. 1975. Vol. 9. N1. Pp. 1-27.

13. Scudiero D.A., Shoemaker R.H., Paull K.D., Monks A., Tierney S., Notziger T.H., Currens M.T., Seniff D., Boyd M.K. Evaluation of a soluble tetrazolium/formazan assay for cell growth and drug sensitivity in culture using human and other tumor cell lines // Cancer Res. 1988. Vol. 48. Pp. 4827-4833.

14. Ruzicka L. Perspektiven der Biogenese und der Chemie der Terpene // Pure Appl. Chem. 1963. N6. Pp. $493-524$.

15. Hayek E., Jordis U., Moche W., Saure F. A bicentennial of betulin // Phytochemistry. 1989. N28. Pp. 2229-2242.

16. Ekman R. Lipophilic extractives of the inner bark of birch, Betula verrucosa Ehrh // Finn. Chem. Lett. 1983. N7-8. Pp. 162-165.

17. Ekman R. The suberin monomers and triterpenoids from the outer bark of Betula verrucosa Ehrh // Holzforschung. 1983. Vol. 37. N4. Pp. 205-211.

18. Cole B., Bentley M., Hua Y., Bu L. Triterpenoid constituens in the outer bark of Betulaalleghaniensis (yellow birch) // J. Wood Chem. Technol. 1991. Vol. 11. N2. Pp. 209-223. 
19. Seshadri T.,Vedantham T. Chemical examination of the barks and heartwoods of betula species of american origin // Phytochemistry. 1971. Vol. 10. N4. Pp. 897-898.

20. HuaY., Bentley M., Cole B., Murray K., Alford R. Triterpenes from the Outer Bark of Betulanigra // J. Wood Chem. Technol. 1991. Vol. 11. N4. Pp. 503-516.

21. Habiyaremye I., Stevanovic-Janezic B., Garneau F.-X., Riedl B., Jean F.-I. Pentacyclictriterpene constituents of yellow birch (Betulaalleghaniensis) bark from Quebec // J. Wood Chem. Technol. 2002. Vol. 22. N2. Pp. 83-91.

22. Похило Н.Д., Уварова Н.И. Изопреноиды различных видов рода Betula // Химия природных соединений. 1988. №3. С. 325-341.

23. Кабанов В.А., Зубов В.П., Семчиков Ю.Д. Комплексо-радикальная полимеризация. М., 1987. 256 с.

24. Володина В.И., Тарасов А.И., Спасский С.С. Полимеризация аллиловых соединений // Успехи химии. 1970. Т. 39. №2. С. 276-303.

25. Zubov V.P., Lachinov M.B., Golubev V.B., Kulikova V.F., Kabanov V.A., Polak L.S., Kargin V.A. The influence of complex agents on the polymerization of vinyl and allyl monomers // J. Polym. Sci. C. 1968. Vol. 23. N1. Pp. 147-155.

26. Куликова В.Ф., Савинова И.Ф., Зубов В.П., Кабанов В.А., Полак Л. С., Каргин В.А. Влияние комплексообразователя на полимеризацию аллильных мономеров // Высокомолекулярные соединения. А. 1967. Т. 9. №2. C. 299-302.

27. Корнильева В.Ф., Мастерова М.Н., Гарина Е.С., Зубов В.П., Кабанов В.А., Полак Л.С., Каргин В.А. Полимеризация аллилового спирта и аллилацетата в присутствии хлористого цинка // Высокомолекулярные соединения. А. 1971. Т. 13. №8. С. 1830-1843.

28. Зубов В.П., Гарина Е.С., Корнильева В.Ф., Мастерова М.Н., Кабанов В.А., Полак Л.С. Полимеризация аллиловых мономеров в присутствии фосфорной кислоты // Высокомолекулярные соединения. А. 1973. Т. 15 . №1. C. $100-106$.

29. Мастерова М.Н., Андреева Л.И., Зубов В.П., Полак Л.С., Кабанов В.А. Полимеризация аллиламинов в присутствии протонных кислот // Высокомолекулярные соединения. А. 1976. Т. 18. №9. С. 1957-1962.

30. Zubov V.P., Kumar M. Vijaya, Masterova M.N., Kabanov V.A. Reactivity of allyl monomers in radikal polymerization // J. Macromol. Sci. A. 1979. Vol. 13. N1. Pp. 111-131.

31. Зубов В.П. Эффекты комплексообразования в радикальной полимеризации: дисс. ... д-ра хим. наук. М., 1970.

32. Hill D.J.T., O'Donnell J.J., O'Sullivan P.W. The role of donor-acceptor complexes in polymerization // Prog. Polym. Sci. 1982. Vol. 8. N3. Pp. 215-276.

33. Зубов В.П., Голубев В.Б., Стояченко И.Л. Новое в чередующейся сополимеризации. М., 1983. 214 с.

34. Коршак В.В., Штильман М.И., Залукаева Т.П. Сополимеры N-винилпирролидона и аллильных мономеров // Высокомолекулярные соединения. Б. 1979. Т. 21. №12. С. 912-916.

35. Панарин Е.Ф., Тарасова Н.Н., Горбунова О.П. Сополимеризация N-винилпирролидона с моноаллиламмониевыми солями // Журнал прикладной химии. 1993. Т. 66. №11. С. 2525-2529.

36. Агеев А.И., Езриелев А.И., Роскин Е.С. Влияние строения аллильных аминов на относительные активности при сополимеризации с акрилонитрилом в различных средах // Высокомолекулярные соединения. А. 1968. T. 10. №11. С. 2460-2464.

37. Агеев А.И., Езриелев А.И., Мазо Л.Д., Роскин Е.С. О константах сополимеризации акрилонитрила и некоторых солей аллильных и металлильных аминов // Высокомолекулярные соединения. А. 1970. Т. 12. №9. С. $1983-1986$.

38. Толстиков Г.А., Флехтер О.Б., Шульц Э.Э., Балтина Л.А., Толстиков А.Г. Бетулин и его производные. Химия и биологическая активность // Химия в интересах устойчивого развития. 2005. Т. 13. С. 1-30.

39. Krasutsky P. A. Birch bark research and development // Nat. prod. rep. 2006. Vol. 23. N6. Pp. 919-942.

40. Alakurtti S., Mäkelä T., Koskimies S., Yli-Kauhaluoma J. Pharmacological properties of the ubiquitous natural product betulin // Europ. J. Pharm. Sciences. 2006. Vol. 29. Pp. 1-13.

Поступило в редакиию 23 января 2014 г.

После переработки 10 декабря 2014 г. 


\title{
Gorbunova M.N. , Krainova G.F., Tolmacheva I.A., Grishko V.V. SYNTHESIS OF NEW BIOLOGICALLY ACTIVE POLYMER BIOCONJUGATES ON THE BASIS OF LUPANE ALLYLAMIDES
}

\author{
Institute of Technical Chemistry of Ural Branch of RAS, ul. ac. Korolev, 3, Perm, 614013 (Russia), \\ e-mail:mngorb@newmail.ru
}

The work is devoted to the synthesis of new copolymers based on allylamides of betulonic and 2 hydroximinobetulonic acids and study of their cytotoxic activity. Allylamides of betulonic and 2 hydroximinobetulonic acids were prepared by the reaction of corresponding acids with allylamine in the presence of oxalyl chloride and triethylamine. It was established that the allylamides obtained do not homopolymerize, but copolymerize with low rates with acrylonitrile and N-vinylpyrrolidone in the presence of radical initiators The investigations of radical copolymerization of allylamides with acrylonitrile and $\mathrm{N}$-vinylpyrrolidone showed that the resulting copolymers have a statistical distribution of the comonomer units in the macromolecule, wherein in the entire range of monomer concentrations the copolymers are enriched by the vinyl monomer units. The copolymerization rates are considerably reduced by increasing the content of allylamides in the initial monomer mixture in all copolymerization systems, the copolymerization rate of allylamide with acrylonitrile is higher than with $\mathrm{N}$-vinylpyrrolidone. At the copolymerization in bulk with enhancing degree of conversion there is a "gel-effect", which is associated with an increasing of the viscosity in the absence of solvent; at the copolymerization in solution "gel-effect" is absent. The structure of the copolymers obtained was determined by ${ }^{1} \mathrm{H}$ NMR spectroscopy. It was established that the products obtained are a mixture of copolymers of allyl amides and oligomers thereof. In the spectra of the reaction products a number of additions of the vinyl monomer with the participating of double bond of isopropylidene group is also observed. The copolymers obtained have a cytotoxic activity: the copolymer of allylamide of betulonic acid with N-vinylpyrrolidone exhibits 4-fold higher activity against MS culture when compared with the initial ally amide and is promising for developing new bioactive polymer bioconjugates.

Keywords: Lupanova allylamides, radical copolymerization, cytotoxic activity.

\section{References}

1. $\quad$ Lee S.M., Min B.S., Lee C.G., Kim K.S., Kho Y.H. Planta Med. 2003, vol. 69, no. 11, pp. 1051-1054.

2. Tolstikova T.G., Sorokina I.V., Tolstikov G.A., Tolstikov A.G., Flekhter O.B. Rus. J. Bioorg. Chem. 2006, vol. 32, no. 3, pp. 291-307.

3. Era V., Jaaskelamen P., Ukkonen K. J. Amer. Oil Chem. Soc. 1981, vol. 58, no. 1, pp. 20-23.

4. Era V., Mustonen T., Jaaskelainen P. Mackromol. Chem. Rapid Commun. 1981, Vol. 2, pp. 283-286.

5. Patent 1671666 (SU). 1991. (in Russ.).

6. Flehter O.B., Ashavina O.Ju., Boreko E.I., Karachurina L.T., Pavlova N.I., Kabal'nova N.N., Savinova O.V., Galin F.Z., Nikolaeva S.N., Zarudij F.S., Baltina L.A., Tolstikov G.A. Himiko-farmacevticheskij zhurnal, 2002, vol. 36, no. 6, pp. 21-24. (in Russ.).

7. Patent 2477134 (RU). 2013. (in Russ.).

8. Flehter O.B., Nigmatullina L.R., Baltina L.A., Karachurina L.T., Galin F.Z., Zarudij F.S., Tolstikov G.A., Boreko E.I., Pavlova N.I., Nikolaeva S.N., Savinova O.V. Himiko-farmacevticheskij zhurnal, 2002, vol. 36, no. 9, pp. 26-28. (in Russ.).

9. Tolmacheva I.A., Grishko V.V., Boreko E.I., Savinova O.V., Pavlova N.I. Himija prirodnyh soedinenij, 2009, no. 5, pp. 566-568. (in Russ.).

10. Krajnova G.F., Tolmacheva I.A., Gorbunova M.N., Grishko V.V. Himija prirodnyh soedinenij, 2013, no. 2, pp. 239242. (in Russ.).

11. Finemann M., Ross S.D. J. Polym. Sci. 1950, vol. 5, pp. 269-284.

12. Kelen T., Tüdős F. J. Macromol. Sci., Chem. 1975, vol. 9, no. 1, pp. 1-27.

13. Scudiero D.A., Shoemaker R.H., Paull K.D., Monks A., Tierney S., Notziger T.H., Currens M.T., Seniff D., Boyd M.K. Cancer Res. 1988, vol. 48, pp. 4827-4833.

14. Ruzicka L. Pure Appl. Chem. 1963, no. 6, pp. 493-524.

15. Hayek E., Jordis U., Moche W., Saure F. Phytochemistry, 1989, no. 28, pp. 2229-2242.

16. Ekman R. Finn. Chem. Lett. 1983, no. 7-8, pp. 162-165.

17. Ekman R. Holzforschung, 1983, vol. 37, no. 4, pp. 205-211.

18. Cole B., Bentley M., Hua Y., Bu L. J. Wood Chem. Technol. 1991, vol. 11, no. 2, pp. 209-223.

19. Seshadri T.,Vedantham T. Phytochemistry, 1971, vol. 10, no. 4, pp. 897-898.

20. HuaY., Bentley M., Cole B., Murray K., Alford R. J. Wood Chem. Technol. 1991, vol. 11, no. 4, pp. 503-516.

21. Habiyaremye I., Stevanovic-Janezic B., Garneau F.-X., Riedl B., Jean F.-I. J. Wood Chem. Technol. 2002, vol. 22, no. 2, pp. 83-91.

22. Pohilo N.D., Uvarova N.I. Himija prirodnyh soedinenij, 1988, no. 3, pp. 325-341. (in Russ.).

23. Kabanov V.A., Zubov V.P., Semchikov Ju.D. Komplekso-radikal'naja polimerizacija. [Complexo-radical polymerization]. Moscow, 1987, 256 p. (in Russ.).

24. Volodina V.I., Tarasov A.I., Spasskij S.S. Uspehi himii, 1970, vol. 39, no. 2, pp. 276-303. (in Russ.).

25. Zubov V.P., Lachinov M.B., Golubev V.B., Kulikova V.F., Kabanov V.A., Polak L.S., Kargin V.A. J. Polym. Sci. C. 1968, vol. 23, no. 1, pp. 147-155.

26. Kulikova V.F., Savinova I.F., Zubov V.P., Kabanov V.A., Polak L. S., Kargin V.A. Vysokomolekuljarnye soedinenija. A. 1967, vol. 9, no. 2, pp. 299-302. (in Russ.).

\footnotetext{
"Corresponding author.
} 
27. Kornil'eva V.F., Masterova M.N., Garina E.S., Zubov V.P., Kabanov V.A., Polak L.S., Kargin V.A. Vysokomolekuljarnye soedinenija. A. 1971, vol. 13, no. 8, pp. 1830-1843. (in Russ.).

28. Zubov V.P., Garina E.S., Kornil'eva V.F., Masterova M.N., Kabanov V.A., Polak L.S. Vysokomolekuljarnye soedinenija. A. 1973, vol. 15, no. 1, pp. 100-106. (in Russ.).

29. Masterova M.N., Andreeva L.I., Zubov V.P., Polak L.S., Kabanov V.A. Vysokomolekuljarnye soedinenija. A. 1976, vol. 18, no. 9, pp. 1957-1962. (in Russ.).

30. Zubov V.P., Kumar M. Vijaya, Masterova M.N., Kabanov V.A. J. Macromol. Sci. A. 1979, vol. 13, no. 1, pp. 111-131.

31. Zubov V.P. Jeffekty kompleksoobrazovanija $v$ radikal'noj polimerizacii: diss. dokt. him. nauk. [Effects of complexation in radical polymerization: doctor chemical sciences diss.]. Moscow, 1970. (in Russ.).

32. Hill D.J.T., O’Donnell J.J., O’Sullivan P.W. Prog. Polym. Sci. 1982, vol. 8, no. 3, pp. 215-276.

33. Zubov V.P., Golubev V.B., Stojachenko I.L. Novoe v cheredujushhejsja sopolimerizacii. [New in the alternating copolymerization]. Moscow, 1983, 214 p. (in Russ.).

34. Korshak V.V., Shtil'man M.I., Zalukaeva T.P. Vysokomolekuljarnye soedinenija. B. 1979, vol. 21, no. 12, pp. 912 916. (in Russ.).

35. Panarin E.F., Tarasova N.N., Gorbunova O.P. Zhurnal prikladnoj himii. 1993, vol. 66, no. 11, pp. 2525-2529. (in Russ.).

36. Ageev A.I., Ezrielev A.I., Roskin E.S. Vysokomolekuljarnye soedinenija. A. 1968, vol. 10, no. 11, pp. 2460-2464. (in Russ.).

37. Ageev A.I., Ezrielev A.I., Mazo L.D., Roskin E.S. Vysokomolekuljarnye soedinenija. A. 1970, vol. 12, no. 9, pp. 1983-1986. (in Russ.).

38. Tolstikov G.A., Flehter O.B., Shul'c Je.Je., Baltina L.A., Tolstikov A.G. Himija v interesah ustojchivogo razvitija, 2005, vol. 13, pp. 1-30. (in Russ.).

39. Krasutsky P. A. Nat. prod. rep. 2006, vol. 23, no. 6, pp. 919-942.

40. Alakurtti S., Mäkelä T., Koskimies S., Yli-Kauhaluoma J. Europ. J. Pharm. Sciences. 2006, vol. 29, pp. 1-13.

Received January 23, 2014

Revised December 10, 2014 
